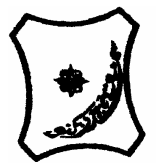

Bayero Journal of Pure and Applied Sciences, 4(2); 173 - 177

Received: May, 2011

Accepted: October, 2011

ISSN $2006-6996$

\title{
EFFECT OF PALM OIL MILL EFFLUENT AND NPK 15:15:15 FERTILIZER ON THE GROWTH AND YIELD OF SOYA BEAN
}

\author{
${ }^{1}$ *Falodun, E.J., Osaigbovo, A.U. and ${ }^{2}$ Remison, S.U. \\ ${ }^{1}$ Department of Crop Science, Faculty of Agriculture, University of Benin, Benin City, Nigeria. \\ ${ }^{2}$ Department of Crop Science, Faculty of Agriculture, Ambrose Ali University, Ekpoma, Edo State, Nigeria. \\ *Correspondence author: ehifalodun@yahoo.com
}

\begin{abstract}
A field study was carried out in the rainforest ecological zone of Nigeria to determine the effect of palm oil mill effluent and NPK 15:15:15 fertilizer on the growth and yield of soyabean genotype (Glycine max L). The experiment was laid out in a randomized complete block design (RCBD) with three replicates in six treatments viz; 0, 100, 200 and $300 \mathrm{~kg} / \mathrm{ha}$ NPK and 5 and $10 \mathrm{t} / \mathrm{ha}$ of POME. The parameters evaluated were plant height, number of leaves, number of branches, leaf area, number of pods, weight of pods, number of branches, weight of grains, grain yield in $\mathrm{Kg} / \mathrm{ha}$ and shelling percentage. The Results showed that soyabean responded to POME at 5 and 10t/ha while NPK fertilization at $200 \mathrm{~kg} / \mathrm{ha}$ resulted in significant increase in grain yield from 1416 to $3213.33 \mathrm{~kg} / \mathrm{ha}$ in one instance. Further more, inorganic fertilizer application resulted in higher vegetatative growth than POME.
\end{abstract}

Keywords: fertilizer, soyabean, NPK, inorganic, vegetative growth.

\section{INTRODUCION}

Soyabean (Glycine max (L) Merr.) produces high quality oil which is highly digestible, high in saturated fatty acids and contains no cholesterol. Soyabean seeds have $40-42 \%$ of its weight as high quality protein with substantial levels of most essential amino acids which being non- synthesizable by humans but must be supplied by diet . Carbohydrate content of the seed averages $38 \%$ with total soluble sugars amounting to about $10 \%$. The oligosaccharide fraction, which causes flatulence, is low, thereby making soyabean an idea food for infants. After oil extraction, the cake residue constitutes a variable source of protein for livestock feeds. Nutrients in Inorganic fertilizers are readily available for uptake upon application while the organic form of nutrients is slowly available (Leo et al., 2001). Orellana et al. (1990) reported that application of fertilizers at the rate of $20 \mathrm{kgN}$ with $35 \mathrm{Kg} \mathrm{P} \mathrm{P}_{2} \mathrm{O} /$ ha gave greater number of leaves and branches in soya bean. Singh and Saxena (1972) in a study on effect of inoculation and NPK fertilizers on soyabean reported that lower rates of nitrogen $(25 \mathrm{~kg} / \mathrm{ha})$ decreased grain yield of soyabean, while higher rates tend to restore yield, but was not economical to farmers. Similarly, Nimje and Seth (1988) reported that inorganic and organic sources gave higher productivity of soyabean when applied in combination than when applied alone. Kihanda (1996) reported that farmers had deviced ways of restoring and maintaining soil fertility which included application of organic fertilizer to offset the nutrients removed by the crops. Recycling part of the nutrients through the use of manure or leave the crop residue in the field to decompose and offset soil organic matter losses. William et al. (1991) recommended organic application on cabbage production in the tropics based on the fact that organic manure improves soil water availability through retention, aeration and better response of crops to fertilizers. Titiloye et al. (1985) used different organic wastes or manures in Nigeria, these include sewage, poultry droppings, cocoa husk and sawdust in growing maize and reported a significant effect on yield. Organic fertilizers supply the needed nutrients elements through microbial assistance and improved soil physical properties (Odu and Mba, 1991). A major constraint to the utilization of animal manure appears to be related to the high quantities, required to make a significant impact on crop yields. In agricultural practices, there is need for additional nutrient for optimum crop performance with the use of effluents. Effluents are organic manures applied to agricultural land. They may be produced on the farm or supplied from other sources such as treated sewage, sludge and some industrial wastes. Liquid waste called effluent and solid waste are produced by food processing plants and other types of agricultural factories such as vegetable oil factories, cane sugar factories, palm oil factories and breweries (Tan, 2000). Palm oil mill effluent (POME) is one of the by products released from an oil palm mill. POME is a brownish oily liquid obtained after extraction of palm oil. It is obtained from two main stages in the palm oil mill factory; sterilization and clarification. The oily liquid present in the fruit forms the effluent. POME contains relatively high amount of plant nutrients particularly potassium $(\mathrm{K})$, nitrogen $(\mathrm{N})$, magnesium $(\mathrm{Mg})$ and calcium (Ca) but its quite low in phosphorous ( $P$ ) Lim et $a /, 1993$. Treated effluent of chemical industry applied at $10 \mathrm{ml} /$ volume in water was found to be effective in promoting germination, growth, chlorophyll and protein contents of Vigna radiate and Vigna mumgo and the production of Napier grass increased significantly with rubber effluent. A four year tolerance trial with rubber with more frequent applications gave similar encouraging results. 
The tree grew as well as or better than similar tree growing along side, which were receiving the standard plantation fertilizer (Wood, 1977). Chan and Chooi (1982) also found out that when the effluents are dried into sludge cake (40\% moisture), stages of perennial crops in the field and when sprayed also advanced maturity of maize, sorghum and soyabean. The aim of the study was to investigate the influence of POME and NPK fertilizer on the agronomic performance of soyabean with a view to determining their optimum levels for the crop.

\section{MATERIALS AND METHODS}

The experiments were conducted on a piece of land $\left(6^{\circ} 19 \mathrm{~N}\right.$ and $\left.5^{\circ} 37 \mathrm{E}\right)$. Temperatures during the growing period ranged between $20.5-34.2^{\circ} \mathrm{C}$ with an average of $27.3^{\circ} \mathrm{C}$. The rainy season started in May and ended 15 October (Table 1). The soils are sandy, loam and slightly acidic (Table 2). The portion of land for the experiment had been left to fallow for one year and was over grown with spear grass (Imperata cylindrica) and siam weed (Chromoleana odorata). Variety of soyabean used was TGX 1440 . The palm oil mill effluent used was sourced from Nigerian institute for oil palm research (NIFOR) analyzed and the chemical composition shown (Table 3).

\section{Treatments}

Six treatments were arranged in a randomized complete block design and replicated three times. Each replicate was separated from each other by $1 \mathrm{~m}$ pathway for easy agronomic operations. The trial was conducted on a flat leveled land and each experimental plot measured 3x $3.6 \mathrm{~m}$. Soyabeans were planted in May and November, 2004, for trial 1 and 2 respectively. Two seeds were planted per stand at a depth of $5 \mathrm{~cm}$ and a spacing of $60 \mathrm{~cm}$ between rows and $10 \mathrm{~cm}$ within rows and later thinned at four leaves stage to 1 seedling per stand a week after germination .The trial received $0,100,200$ and 300 $\mathrm{kg} / \mathrm{ha}$ NPK and 5 and $10 \mathrm{t} / \mathrm{ha}$ palm oil mill effluents for two weeks before planting. Weeds were controlled manually at 3 and 7 weeks after planting .The second trial was under sprinkler irrigation because it was planted in the dry season.

\section{DATA COLLECTION}

Growth parameters measured on five randomly selected plants were plant height $(\mathrm{cm})$, number of leaves per plant, leaf area $\left(\mathrm{cm}^{2}\right)$ and number of branches per plant. At harvest, number of pods/net plot, weight of pods/net plot, weight of grains/net plot and shelling percentage were computed.

The data collected were subjected to analysis of variance (ANOVA) as described by Gomez and Gomez (1984) and significant differences among treatment means were separated using the least significant difference (LSD) at $5 \%$ level of significance (Steel and Torrie, 1982).

\section{RESULTS}

\section{Vegetative Characters}

There was increase in the vegetative characters of soyabean at various stages of growth when compared with the control in both trial (Tables 4 and 5). However, the applications of inorganic fertilizers enhanced more vegetative growth when compared with the POME. Increase application rate of POME at $10 \mathrm{t} /$ ha increased the plant height and number of branches when compared with lower application rate of $5 \mathrm{t} / \mathrm{ha}$ POME. Application of $200 \mathrm{~kg} / \mathrm{ha}$ NPK fertilizers tend to be more favourable under this application and had higher plant height, number of branches, number of leaves and leaf area.

\section{Reproductive Characters}

There was a significant difference amongst treatment $(P \leq 0.05)$ in the performance of the soya bean plant (Tables 6 and 7). Number of pods, weights of pods, weights of grains and grain yield $(\mathrm{Kg} / \mathrm{ha})$ increased with the application of inorganic fertilizer up to the highest yield $(200 \mathrm{~kg} / \mathrm{ha} N P K)$. Increase in the rate of application of POME increased the Reproductive characters. Grain yield of soyabean treated with inorganic fertilizer were significantly higher than yields treated with POME and the control. The highest grain yield $(3213.33 \mathrm{~kg} / \mathrm{ha})$ was recorded with crops treated with $200 \mathrm{~kg} / \mathrm{ha}$ inorganic fertilizer.

\section{DISCUSSION}

Increase in the vegetative traits of plants treated with moderate application of NPK $200 \mathrm{~kg} / \mathrm{ha}$ may be attributed to internodes elongation and other nutrients received by the plant from inorganic sources. This result is comparable to the findings of Leo, (2001) who reported that nutrients in inorganic fertilizer are readily available for plant uptake upon application while the organic forms of nutrients are slowly available. Orellana et al, 1990 also agreed that moderate application of fertilizer gave greater number of leaves and branches of soyabeans.Decrease in vegetative characters as seen with plants in which POME was applied could be due to the slow release of nutrients in the organic form to plants. Another reason could be non availability of some nutrients which may have been fixed in the soil. This confirms the findings of Tisdale et al, (1985) who reported that the availability of $\mathrm{Mg}$ decreased as the $\mathrm{pH}$ approaches neutrality. The lowest plant height, number of leaves, number of branches, leaf area as seen with the control may be due to the fact that plants had to depend mainly on the intrinsic soil fertility. The highest grain yield $(3213.33 \mathrm{~kg} / \mathrm{ha})$ was recorded with crops treated with $200 \mathrm{~kg} / \mathrm{ha}$ inorganic fertilizer. This observation correspond with the report of Jayapaul and Ganesaraja (1970), as well as Kumar and Rao (1971) that moderate application of nitrogen and phosphorous increase the number of pods per plant, seeds per pod, seed weight and seed yield of soyabean. Increase in grain yield of soyabean due to nitrogen applications may probably be as a result of the vital role of nitrogen in the synthesis of chlorophyll and amino acids which are indispensible ingredients of the process of autotrophization.

Nitrogen influences the grain production of photosynthates and their increased translocation to reproductive characters. 
Bajopas Volume 4 Number 2 December, 2011

Table 1. Meterological conditions at NIFOR Benin City during the period of the trial, May 2004 January 2005

\begin{tabular}{llllllllll}
\hline & May & June & Jul & Aug & Sept & Oct & Nov & Dec & Jan \\
\hline Total Rainfall $(\mathrm{mm})$ & 323.4 & 355.7 & 214.3 & 398.6 & 293.7 & 280.7 & 32.3 & 5.0 & 32.2 \\
Min. Temp. $\left({ }^{\circ} \mathrm{C}\right)$ & 23.0 & 22.8 & 21.8 & 21.8 & 23.3 & 22.9 & 23.4 & 20.5 & 22.5 \\
Max. $\left({ }^{0} \mathrm{C}\right)$ & 31.5 & 30.7 & 30.7 & 29.8 & 31.2 & 32.5 & 33.2 & 34.2 & 33.4 \\
Rel. Humidity & 84.8 & 87.8 & 81.5 & 90.0 & 85.2 & 82.4 & 83.2 & 75.5 & 74.4 \\
Solar Rad. & 384.9 & 359.6 & 2943 & 294.8 & 320.1 & 385.2 & 358.2 & 389.2 & 364.1 \\
Mean Sunshine (hr/day) & 4.5 & 4.2 & 2.7 & 1.4 & 3.8 & 4.2 & 41 & 6.3 & 7.1 \\
\hline
\end{tabular}

Table 2. Physical and chemical properties of soils from experimental site

\begin{tabular}{lll}
\hline Soil Variable & Exp 1 & Exp 2 \\
\hline Clay $(\%)$ & 3.00 & 4.50 \\
Silt (\%) & 1.80 & 3.50 \\
Sand (\%) & 95.20 & 92.20 \\
Textural group & Sandy loam & Sandy loam \\
pH $(1.1)$ & 4.80 & 4.80 \\
Organic Carbon $(\%)$ & 1.12 & 1.66 \\
C/N & 43.60 & 60.00 \\
Nitrogen $(\%)$ & 0.10 & 0.21 \\
Phosphorous $(\mathrm{Mg} / \mathrm{kg})$ & 3.78 & 9.80 \\
Sodium $(\mathrm{Cmol} / \mathrm{kg})$ & 0.18 & 0.63 \\
Potassium $(\mathrm{Cmol} / \mathrm{kg})$ & 0.10 & 0.83 \\
Calcium $(\mathrm{Cmol} / \mathrm{kg})$ & 2.10 & 2.10 \\
Magnesium $(\mathrm{Cmol} / \mathrm{kg})$ & 0.80 & 0.32 \\
\hline
\end{tabular}

Table 3. Chemical composition of palm oil mill effluent (POME)

\begin{tabular}{ll}
\hline Nutrients & Composition \\
\hline $\mathrm{pH}$ & 4.8 \\
Ash & 13.00 \\
Carbon $(\mathrm{C})$ & $2.30-2.60$ \\
Nitrogen $(\mathrm{N})$ & $1.80-2.30$ \\
Phosphorus $(\mathrm{P})$ & 2.40 \\
Potassium $(\mathrm{K})$ & 3.05 \\
Magnesium $(\mathrm{Mg})$ & 1.07 \\
Calcium $(\mathrm{Ca})$ & 0.25 \\
Sodium $(\mathrm{Na})$ & 0.13 \\
\hline
\end{tabular}

Table 4: Effects of Fertilizer application on Vegetative Characters, Experiment 1

\begin{tabular}{lllll}
\hline Treatment & $\begin{array}{l}\text { Plant } \\
\text { height(cm) }\end{array}$ & No. of leaves & $\begin{array}{l}\text { Leaf } \\
\text { area(cm }\end{array}$ & Number of branches \\
\hline Control & 161.00 & 132.30 & 31937.22 & 20.60 \\
NPK 100(kg/ha) & 220.00 & 181.60 & 61593.06 & 29.60 \\
NPK 200(kg/ha) & 227.60 & 221.30 & 80176.99 & 34.00 \\
NPK 300(kg/ha) & 196.60 & 190.00 & 73245.00 & 33.00 \\
POME (5t/ha) & 176.30 & 173.60 & 62861.18 & 26.60 \\
POME (10t/ha) & 180.30 & 157.60 & 41212.26 & 27.00 \\
Mean & 193.03 & 177.68 & 59121.11 & 27.85 \\
LSD (0.05) & 26.57 & 56.42 & 82.85 & 5.26 \\
CV (\%) & 4.85 & 8.00 & 7.42 & 10.18
\end{tabular}

Table 5: Effects of Fertilizer application on Vegetative Characters . Experiment 2

\begin{tabular}{|c|c|c|c|c|c|}
\hline Treatment & $\begin{array}{l}\text { Plant } \\
\text { height(cm) }\end{array}$ & No. of leaves & $\begin{array}{l}\text { Leaf } \\
\text { area }\left(\mathrm{cm}^{2}\right)\end{array}$ & Number of & branches \\
\hline Control & 161.30 & 128.30 & 30971.60 & 20.60 & \\
\hline NPK $100(\mathrm{~kg} / \mathrm{ha})$ & 219.30 & 246.60 & 80687.05 & 28.60 & \\
\hline NPK $200(\mathrm{~kg} / \mathrm{ha})$ & 228.30 & 188.60 & 68386.30 & 33.60 & \\
\hline NPK 300(kg/ha) & 197.00 & 190.00 & 75202.00 & 32.60 & \\
\hline POME (5t/ha) & 174.60 & 191.30 & 57062.30 & 27.30 & \\
\hline POME (10t/ha) & 180.60 & 150.30 & 43276.90 & 26.30 & \\
\hline Mean & 193.03 & 177.68 & 59121.11 & 27.85 & \\
\hline LSD (0.05) & 26.58 & 54.42 & 81.57 & 5.25 & \\
\hline CV (\%) & 4.90 & 12.78 & 7.37 & 10.06 & \\
\hline
\end{tabular}


Table 6: Effects of Fertilizer Application on Yield and Yield Components. Experiment 1

\begin{tabular}{|c|c|c|c|c|c|}
\hline Treatment & $\begin{array}{l}\text { No of pods } \\
\text { /plant }\end{array}$ & $\begin{array}{l}\text { Wt of pods }(\mathbf{g}) \\
\text { /plant }\end{array}$ & $\begin{array}{l}\text { Wt of grains } \\
\text { (g)/plant }\end{array}$ & $\begin{array}{l}\text { Shelling } \\
\%\end{array}$ & $\begin{array}{l}\text { Grain yield } \\
\text { (kg/ha) }\end{array}$ \\
\hline Control & 225.10 & 62.84 & 42.51 & 67.13 & 1416.60 \\
\hline $\begin{array}{l}\text { NPK } \\
(100 \mathrm{~kg} / \mathrm{ha})\end{array}$ & 367.01 & 102.00 & 82.42 & 80.70 & 2733.30 \\
\hline $\begin{array}{l}\text { NPK } \\
(200 \mathrm{~kg} / \mathrm{ha})\end{array}$ & 511.31 & 146.80 & 96.40 & 65.62 & 3213.33 \\
\hline $\begin{array}{l}\text { NPK } \\
(300 \mathrm{~kg} / \mathrm{ha})\end{array}$ & 455.32 & 120.160 & 80.61 & 66.71 & 2686.63 \\
\hline POME (5t/ha) & 255.02 & 76.40 & 52.31 & 68.50 & 1746.60 \\
\hline $\begin{array}{l}\text { POME } \\
(10 \mathrm{t} / \mathrm{ha})\end{array}$ & 259.01 & 94.40 & 63.90 & 67.70 & 21331.30 \\
\hline Mean & 343.79 & 100.50 & 69.169 & 69.39 & 1321.62 \\
\hline LSD $P<0.05$ & 46.80 & 48.83 & 30.87 & 31.42 & 35.43 \\
\hline
\end{tabular}

Table 7: Effects of Fertilizer Application on Yield and Yield components (Experiment 2)

\begin{tabular}{|c|c|c|c|c|c|}
\hline Treatment & $\begin{array}{l}\text { No of pods } \\
\text { /plant }\end{array}$ & $\begin{array}{l}\text { Wt of pods (g) } \\
\text { /plant }\end{array}$ & $\begin{array}{l}\text { Wt of grains } \\
\text { (g)/plant }\end{array}$ & $\begin{array}{l}\text { Shelling } \\
\%\end{array}$ & $\begin{array}{l}\text { Grain yield } \\
\text { (kg/ha) }\end{array}$ \\
\hline Control & 166.30 & 63.11 & 42.87 & 67.92 & 1429.00 \\
\hline $\begin{array}{l}\text { NPK } \\
(100 \mathrm{~kg} / \mathrm{ha})\end{array}$ & 315.31 & 101.75 & 83.05 & 81.62 & 2768.33 \\
\hline $\begin{array}{l}\text { NPK } \\
(200 \mathrm{~kg} / \mathrm{ha})\end{array}$ & 468.01 & 146.97 & 96.07 & 65.36 & 5202.33 \\
\hline $\begin{array}{l}\text { NPK } \\
(300 \mathrm{~kg} / \mathrm{ha})\end{array}$ & 418.62 & 120.59 & 80.59 & 66.83 & 2686.33 \\
\hline POME (5t/ha) & 257.31 & 76.56 & 52.07 & 68.01 & 1735.66 \\
\hline $\begin{array}{l}\text { POME } \\
\text { (10t/ha) }\end{array}$ & 301.62 & 93.86 & 63.6 & 67.82 & 2122.00 \\
\hline Mean & 321.9 & 100.47 & 69.72 & 69.58 & 2157.27 \\
\hline LSD $P<0.05$ & 46.02 & 48.80 & 31.10 & 31.12 & 35.46 \\
\hline
\end{tabular}

Results of this study suggest that moderate application of inorganic fertilizer has a comparative yield advantage over application of organic fertilizer. However, high level of POME may be applied as the plants responded to the highest level applied in the two trials reported. However, additional studies are needed to confirm the present results.

\section{CONCLUSION AND RECOMMENDATION}

Inorganic fertilizer increased soyabean growth and subsequent yield more than POME. This could be attributed to the fact that nutrient elements in inorganic fertilizers are readily available for plant uptake upon application while the organic forms of

\section{REFERENCES}

Chan and Chooi, (1982). Ponding system for palm oil mill effluent Treatment (PORIM). Regional workshop in Palm oil mill Technology and effluent treatment, Kuala lumpar. Malaysia Society of soil Science, 58: 185 - 192.

Gomez, K.A., and Gomez, A. A (1984). Statistical procedure $2^{\text {nd }}$ Ed., N.Y. John Wiley and Sons, p 680. nutrients are slowly available. Based on the results of this study, it is recommended that moderate rates of NPK fertilizer (100 or $200 \mathrm{~kg} / \mathrm{ha}$ ) can be applied to boost soyabean production. However high levels of POME (10t/ha) may be applied as the plants responded to the highest level applied in the two trials reported.

\section{Acknowledgement}

The authors are grateful to the International Institute for Tropical Agriculture (IITA), Ibadan and Agricultural Development Programme, Edo State, Nigeria for providing the seeds for the research work

Jayapaul, P.and Ganesaraja, V. (1970). Studies of response of soya bean varieties to $\mathrm{N}$ and $\mathrm{P}$. Indian J. Agron, 35: 329 - 330.

Kihanda, F.M. (1996). The role of farmyard manure in improving maize production in the subhumid highlands of central Kenya Ph.D Thesis university of reading, U.K, pp: 7 - 19.

Kumar, K., and Rao, K.V.P. (1971). N and P levels in relationship to dry matter production, $\mathrm{P}$ uptake and their partitioning in soya bean. Annals Agric. Res 12: 270 - 272. 
Leo, E. (2001). Effect of fertilizer on grain yield of soya bean. Eur. J. Agron. 13: 212-221.

Lim, C.H,. PNG, T.C Chan, K.W. and Chooi, S.Y.(1993). Land Application of Digested palm oil Mill effluent (POME) by sprinkle system. Procedings of the seminar on land, application of palm and rubber factory effluents (Lim, KH; Bachik A.J. and Poon YC eds). Malaysia Society of Soil Science, pp: 72- 79.

Nimje. P.M., and Seth, J. (1988). Effect of P and FYM on nutrient uptake by soyabean. Indian $\mathrm{J}$. Agron, 33: $134-142$.

Odu, C.T., and Mba, C.C. (1991). Microbiology consideration for maximizing nutrient availability through organic fertilization. Proceedings of Natural Organic fertilizer Seminar, Kaduna, pp: $67-80$.

Orellana, M., Barber, R.G. and Diaz, O. (1990). Effect of Deep tillage and fertilization on soyabean. J. Agron. Crop Sci. 190: 216 - 223.

Steel, R.G.D., and Torries, J.H. (1982). Principles and Procedure of Statistics. A Biometrical Approach. $2^{\text {nd }}$ ed. London: Mc Graw-Hill International Book Co.
Singh, N.P., and Sexena, M.C. (1972). Field study on Nitrogen fertilization of soyabean Glycine max L Merr. India S. Agric. Sci., 42: 1028 1031.

Tan, K.S. (2000). Preliminary results on land application of digested POME to Mature oil palm on inland soil proc. Semin in land Application of oil palm and Rubb. Fact. Effluents. Serdana and Rubb. Fact. Effluents Serdam 2007 (in Press).

Titiloye, E.O., Lucas, E.O and Agboda, A.A. ( 1985). Evaluation of fertilizer value of organic waste materials in South Western Nigeria. Bio Agric and Hort. 3: $25-37$.

Tisdale, S.H,. Nelson, W.L., and Beaton, D. (1985). Soil fertility and fertilizer. $4^{\text {th }}$ edition published by Macmillian publishing company, New York, 452. pp

William, C.N., \& Peregmine, W.T.H. (1991). Vegetable production in the tropics. Longman scientific Technical Group, pp: 179.

Wood, B. J. (1977). A review of current methods for dealing with palm oil mill effluents. Panter (Kuala lumpar ) 53: $477-496$. 